\title{
Short Communication: Analysis of purity and concentration of DNA extracted from intron patho gene-spin extraction on processed crab food product samples
}

\author{
ALFI SOPHIAN", RATNA PURWANINGSIH, MUINDAR, EKA PUTRI JUNIARTI IGIRISA, \\ MUHAMMAD LUTHFI AMIRULLAH \\ Laboratory of Microbiology, National Agency of Drug and Food Control in Gorontalo. Jl. Tengah Toto Selatan, Bone Bolango 96123, Gorontalo, \\ Indonesia. Tel./fax.: +62-435-822052, `email: alfi.sophian@pom.go.id \\ Manuscript received: 25 August 2020. Revision accepted: 9 June 2021.
}

\begin{abstract}
Sophian A, Purwaningsih R, Muindar, Igirisa EPJ, Amirullah ML. 2021. Short Communication: Analysis of purity and concentration of DNA extracted from intron patho gene-spin extraction on processed crab food product samples. Asian $J$ Trop Biotechnol 18: 28-31. The purpose of this study was to optimize the Intron patho gene-spin DNA/RNA extraction kit on processed crab food products so that it can be used for testing samples, other than viral and bacterial samples. The method used in purity and concentration analysis to analyze total DNA (yield) is the absorbance method using a nanophotometer. The method used to isolate the sample DNA is the centrifuge column or spin column method. The research data showed that the extracted sample concentration was in the range of 15.1515.75 , with an average of 15.46 . While the purity values measured at the A260/A280 wavelengths were obtained with a purity range between 2,124-2,346. The total DNA analysis (yield) results obtained an average of 755.04, with the lowest yield value of 575.50 and the highest yield value of 787.50. As a suggestion for further research, it is hoped that modification can be made to perfect the isolated DNA so that it has better purity and concentration values.
\end{abstract}

Keywords: DNA, gene, intron, PCR, RNA

\section{INTRODUCTION}

Processed crab food products are very popular with Indonesians. The process of processing it into other food ingredients such as chips, crackers and frozen food is a way to increase the economic value of processed crab products. The future challenge of this product is the authentication of products whose raw materials have high economic value. The potential for fraud by changing the main raw material is an act of violation of the law.

Currently, POM ensures the quality of goods in circulation is of guaranteed quality and safety. The strategic function of the POM in ensuring high quality is becoming more difficult; especially if improvements in the technical capacity of personnel and the personnel who support their main duties and functions. For this reason, this study was conducted to provide a new reference in the form of test results on processed crab products. With this research, it is hoped that it can become a reference in developing technical testing to support surveillance activities.

In DNA testing, extraction is an early stage that has a very important role in the success of testing using PCR. This is in line with the opinion expressed by Jhosi et al. (2016) and Fulton et al. (1995) which states that DNA extraction is the key to the success of PCR analysis. According to Ibrahim (2010) in PCR analysis, DNA extraction results with good quality and quantity are needed to proceed to the amplification stage. The presence of contaminant compounds in the extracted DNA, such as polysaccharides and polyphenols, makes the enzyme work slow in the PCR amplification process (Hoarau et al. 2007). The Intron patho gene-spin (viral DNA/RNA) extraction kit is an extraction kit made for the extraction of DNA and RNA virus types. However, this kit can also be used for plasma, blood, serum cell-free body fluids, cells, and tissue samples. Because one of the specifications of this kit is that it can be used to extract cell and tissue samples, it is possible that this kit can be used to extract processed crab food products.

The novelty aspect of this research is to optimize the Intron patho gene-spin DNA/RNA extraction kit against processed crab food products so that it can be used for testing samples, other than virus samples, so it can be used as one of the references in extracting samples from processed crab food products. Additionally it may be a reference source in modifying the types of extraction kits in situations that allow modifications to be made.

\section{MATERIALS AND METHODS}

\section{Materials}

The materials used in this study were processed crab food products, which were sampled from several restaurants selling processed crab menus. Also Intron Patho Gene-Spin (viral DNA/RNA) Extraction (cat. 17154.100) extraction kits were used.

\section{Sample preparation}

Purchased samples from several restaurants were washed clean, so that the crab meat that was to be extracted 
had no other matrix besides crab meat. Furthermore, the crabmeat was then separated between the meat and the shell, after which it is crushed and homogenized. The homogenized sample was then be extracted.

\section{DNA isolation}

The sample was weighed to be $1 \mathrm{~g}$ and put it in a $2 \mathrm{~mL}$ microcentrifuge tube. $500 \mu \mathrm{L}$ of $\mathrm{VL}$ buffer solvent was added. It was incubated for 10 minutes at room temperature, while occasionally vortexing for 1 minute every 2 minutes of incubation. Next $700 \mu \mathrm{L}$ of BL buffer was added and then incubated again for 2 minutes then vortex 1 minute. $750 \mu \mathrm{L}$ of the solution was transferred into the spin column, then centrifuged at a speed of $14.000 \mathrm{rpm}$ for 1 minute. The liquid was discarded before adding 750 RW 1 buffer. This was then put in the centrifuge at a speed of $14.000 \mathrm{rpm}$ for 1 minute. The liquid was discarded, before 750 RW 2 buffer was added. This was then centrifuged at $14.000 \mathrm{rpm}$ for 1 minute. The spin column was transferred into the $1.5 \mathrm{~mL}$ microcentrifuge tube, before adding $50 \mu \mathrm{L}$ of EB buffer. Incubation was for 2 minutes, then centrifuged at $14.000 \mathrm{rpm}$ for 2 minutes. The spin column was discared and the extracted DNA was then calculated for its concentration and purity using a nano photometer.

\section{DNA yield}

After knowing the concentration and purity values, the next step was to calculate the yield. DNA yield is the final DNA product calculated using the formula:

DNA yield $(\mu \mathrm{g})=$ DNA concentration $\times$ total sample volume $(\mathrm{mL})$

\section{Purity and concentration analysis}

Analysis of purity and concentration were performed using a nano photometer NP80 (IMPLEN), method setting; Nucleic acid, dsDNA type, nano volume mode, $2 \mu \mathrm{L}$ sample volume, nucleic acid factor 50.00, background correction $320 \mathrm{~nm}$, air bubble recognition off, manual dilution factor 1.000 .

\section{Data analysis}

Data analysis was performed by comparing the purity and concentration values against the standard DNA extract sample where the purity was in the range (1.8-2.0) while the concentration was greater than $20 \mathrm{ng} / \mathrm{mL}$.

\section{RESULTS AND DISCUSSION}

\section{Data from concentration and purity analysis}

The analysis of concentration and purity was carried out using a nano photometer and the results were obtained (Table 1). From the table, the concentration value of the extracted sample was in the range of 15.15-15.75, with an average of 15.46. The purity values measured at the A260/A280 wavelengths were obtained with a purity range between 2.24-2.346. According to Sambrook et al. (1989), the purity value of DNA extract above 2 indicates that the
DNA extraction results still contain protein contamination. Whereas if the purity results show a value of less than 1.8 , this would indicate that the DNA extract still contains phenol residues and other solvent contaminants.

DNA extraction results are good if the purity value is in the range 1.8-2.0, the concentration is greater than 20 $(\mathrm{ng} / \mu \mathrm{L})$ (Kirby 1990; Artama 1991). However, to conclude that an extracted sample can be tested using real-time PCR, the purity and concentration values that are the benchmark for isolation are said to be good because real-time PCR technology is possible if the amplification process can occur with low concentrations even though it depends. on the sensitivity of a PCR device.

\section{DNA yield}

After analyzing the slides and concentrations, the total or yield DNA was them analyzed. From the research conducted, an average of 755.04 was obtained. With the lowest yield value of 575.50 and the highest yield value of 787.50. Further results are presented in Table 2.

One of the methods to perform yield analysis is by using the absorbance method. This method is done by using a spectrophotometric instrument. The absorbance readings were carried out at a wavelength of $260 \mathrm{~nm}$ or (A260). This is because DNA at this wavelength absorbs light so that the resulting turbidity can be used to estimate the amount of DNA detected. To ensure this, the reading is carried out at the linear range of the instrument $(0.1-1.0)$.

Table 1. Extracted nano photometer data.

\begin{tabular}{lcc}
\hline Sample & $\begin{array}{c}\text { Concentration } \\
\mathbf{n g} / \boldsymbol{\mu L}\end{array}$ & $\begin{array}{c}\text { Purity } \\
\mathbf{( A 2 6 0 / A 2 8 0 )}\end{array}$ \\
\hline Sample 1 & 15.65 & 2.268 \\
Sample 2 & 15.40 & 2.124 \\
Sample 3 & 15.60 & 2.346 \\
Sample 4 & 15.55 & 2.221 \\
Sample 5 & 15.15 & 2.349 \\
Sample 6 & 15.35 & 2.225 \\
Sample 7 & 15.45 & 2.225 \\
Sample 8 & 15.35 & 2.255 \\
Sample 9 & 15.75 & 2.188 \\
Sample 10 & 15.40 & 2.200 \\
Average & 15.46 & 2.240 \\
\hline
\end{tabular}

Table 2. DNA yield.

\begin{tabular}{lccc}
\hline Sample & $\begin{array}{c}\text { Concentration } \\
\mathbf{n g} / \boldsymbol{\mu L}\end{array}$ & $\begin{array}{c}\text { Total dilution } \\
\text { volume }(\boldsymbol{\mu L})\end{array}$ & Yield \\
\hline Sample 1 & 15.65 & 50 & 782.50 \\
Sample 2 & 15.40 & 50 & 770.00 \\
Sample 3 & 15.60 & 50 & 780.00 \\
Sample 4 & 15.55 & 50 & 777.50 \\
Sample 5 & 15.15 & 50 & 575.50 \\
Sample 6 & 15.35 & 50 & 767.50 \\
Sample 7 & 15.45 & 50 & 772.50 \\
Sample 8 & 15.35 & 50 & 767.50 \\
Sample 9 & 15.75 & 50 & 787,50 \\
Sample 10 & 15.40 & 50 & 770.00 \\
Average & 15.46 & 50 & 755.05 \\
\hline
\end{tabular}




\section{Discussion}

The method used was slightly modified at the extraction stage, namely by adding the length of time and incubation temperature. The manual kit suggests the incubation be carried out at room temperature for 10 minutes. In this study, the incubation was carried out at $70^{\circ} \mathrm{C}$ for 30 minutes while occasionally in the vortex. Modifications at this stage were carried out to produce perfect lysis of the sample to be extracted. The observations made on the characteristics of the extracted sample show that the turbidity frame is getting higher with the length of time and homogenization is carried out using the vortex.

Based on the extraction data read using a nano photometer, it is known that the extracted DNA does not have good purity and concentration values. This could be because this kit is made only for the extraction of DNA or RNA viruses, so optimization of the processed crab sample does not guarantee the success of the extraction.

The principle of the extraction kit used in this study was to use the silicon dioxide method, which is made in a spin column that can absorb DNA. This method generally has no difference from the phenol-chloroform method in DNA extraction. This method, DNA extraction, will go through three stages: cell lysis, DNA separation, and DNA purification (Corkill and Rapley 2008). DNA extraction begins with lysis where at this stage the sample is lysed for 30 minutes with occasional vortices every 3 minutes to get a better lysis process.

The observations made on the samples in the vortex showed that the samples were getting cloudier when compared to before vortex. This gives an idea that the cells have undergone lysis which is marked by turbidity occurring in the lysis solution. The lysis process is an important step in DNA extraction because at this stage the trapped DNA in the cell will be removed. The cell lysis process occurs in the early stages of extraction, which works by two mechanisms: enzymatic and chemical. The enzymatic mechanism occurs by adding proteinase-K. According to Surzycki (2000), the proteinase K enzyme functions to break the amino acid carboxyl group in the peptide bonds that make up the peptidoglycan layer of the cell wall. While the chemical mechanism occurs by adding sodium dodecyl sulfate (SDS) detergent. The addition of SDS serves to dissolve lipids in the cell membrane so that cell membrane destabilization occurs and binds to proteins and polysaccharides on the cell membrane to open (Surzycki 2000; Demeke et al. 2009). In the process of cell lysis, the cell wall covering has been destroyed so that the DNA will mix with other cell macromolecules.

According to Held (2001), the analysis of concentration and purity was carried out using a nano photometer, which reads DNA absorption at wavelength A260/A280. However, the absorption reading method at the A260/A280 wavelength is the method most used. Another opinion was expressed by Matlock (2015) which states that the results of the analysis of purity and good concentration on the sample do not guarantee that the sample is successfully amplified. Another equally important factor is the sample itself. However, the purity and concentration analysis method to see the quality and quality of isolated nucleic acids using a nano photometer is an effective method to determine the quality of the extracted results in a short time.

The results of the purity analysis of the samples showed values and concentrations outside the good DNA extraction category were between (1.7-2) for purity and above 20 $\mathrm{ng} / \mu \mathrm{L}$ for concentration. However, Kapa Biosystems (2014) revealed a different matter: to carry out PCR analysis, isolated DNA concentrations with a value between $10-100 \mathrm{ng} / \mu \mathrm{L}$ are needed. However, these results are not necessarily usable, but a confirmation test using PCR is needed. The results of the DNA yield showed that the amount of DNA was quite large, namely around 755.04. This value is very good when compared to the DNA yield value required for DNA amplification using real-time PCR.

It is suggested that this should be continued until the confirmation test stage to prove the results of DNA extraction, even though it does not mean that the category of good DNA extraction results can still be used. This is important because every real-time PCR tool has a different detection limit level so that the accuracy and detection ability will be different. The smallest value that can be detected ranges from 0.01-2 p/ $\mu \mathrm{L}$, (Perandin et al. 2004; Cnops et al. 2011; Kamau et al. 2013; Xu et al. 2015; Srisutham et al. 2017).

Based on the research conducted, it was discovered that the results of the analysis of purity and concentration outside of the DNA standard extracted were good. Therefore in future research, modifications are needed so that the kit used can have good DNA extracted results for use in samples of processed crab food products.

\section{ACKNOWLEDGEMENTS}

The authors would like to thank the Head of the National Agency of Drug and Food Control (NADFC) in Gorontalo, Indonesia for laboratory support.

\section{REFERENCES}

Artama WT. 1991. Genetical manipulation. Center for Inter-UniversityBiotechnology. Gadjah Mada University, Yogyakarta. [Indonesian]

Cnops L, Jacobs J, Van Esbroeck M. 2011. Validation of a four-primer real-time PCR as a diagnostic tool for single and mixed Plasmodium infections. Clin Microbiol Infect 17 (7): 1101-1107. DOI: 10.1111/j.1469-0691.2010.03344.x

Corkill G, Rapley R. 2008. The Manipulation of Nucleic Acid: Basic Tools \& Techniques in Molecular Biomethods Handbook. 2nd ed. Humana Press, New York.

Demeke T, Ratnayaka I, Phan A. 2009. Effects of DNA extraction and purification methods on real-time quantitative PCR analysis of roundup ready soybean. J Assoc Off Anal Chem Int 92 (4): 11361144. DOI: $10.1093 /$ jaoac/92.4.1136

Fulton TM, Chunwongse J, Tanksley SD. 1995. Microprep protocol of extraction DNA from tomato and other herbaceous plants. Plant Mol Biol Rep 13 (3): 207-209. DOI: 10.1007/BF02670897

Held PG. 2001. Nucleic Acid Purity Assessment using A260/A280 Ratios. Application note. Senior Scientist \& Applications Lab Manager. Biotek.

Hoarau G, Coyer JA, Stam WT, Olsen JL. 2007. A fast and inexpensive DNA extraction/purification protocol for brown macroalgae. Mol Ecol Notes 7: 191-193. DOI: 10.1111/j.1471-8286.2006.01587.x 
Ibrahim RIH. 2010. A modified CTAB protocol for DNA extraction from young flower petals of some medicinal plant species. Geneconserve 10 (4): $165-182$.

Joshi RS, Garg P, Zaitlen N, Lappalainen T, Watson CT, Azam N, Ho D, Li X, Antonarakis SE, Brunner HG, Buiting K. 2016. DNA methylation profiling of uniparental disomy subjects provides a map of parental epigenetic bias in the human genome. Am J Hum Genet 99 (3): 555-566. DOI: 10.1016/j.ajhg.2016.06.032

Kamau E, Alemayehu S, Feghali KC, Saunders D, Ockenhouse CF. 2013 Multiplex qPCR for detection and absolute quantification of Malaria. PLoS One 8 (8): e71539. DOI: 10.1371/journal.pone.0071539

Kapa Biosystems. 2014. KAPA2G Fast HotStart PCR Kit Technical Data Sheet. Kapa Biosystems Inc., Wilmington, MA

Kirby LT. 1990. DNA Fingerprinting: An Introduction. M. Stockton Press, New York. DOI: 10.1007/978-1-349-12040-6

Matlock B. 2015. Assessment of Nucleic Acid Purity. Technical Note 52646. Thermo Fisher Scientific, Wilmington, MA, USA

Perandin F, Manca N, Calderaro A, Piccolo G, Galati L, Ricci L, Medici MC, Arcangeletti MC, Snounou G, Dettori G, Chezzi C. 2004.
Development of a real-time PCR assay for detection of Plasmodium falciparum, Plasmodium vivax and Plasmodium ovale for routine clinical diagnosis. J Clin Microbiol 42 (3): $1214 . \quad$ DOI: 10.1128/JCM.42.3.1214-1219.2004

Sambrook J, Fritsch F, Miniatis T. 1989. Molecular Cloning Laboratory Manual. 3rd edition. Cold Spring Harbor Laboratory Pr, New York (US).

Srisutham S, Saralamba N, Malleret B, Re L. 2017. Four human Plasmodium species quantification using droplet digital PCR. PLoS One 12 (4): e0175771. DOI: 10.1371/journal.pone.0175771

Surzycki S. 2000. General aspects of DNA isolation and purification. Basic Tech Mol Biol 1-32. DOI: 10.1007/978-3-642-56968-5_1

Xu W, Morris U, Aydin SB, Msellem MI, Shakely D, Petzold M. 2015. SYBR greeb real-time PCR-RFLP assay targeting the Plasmodium cytochrome B gene-A highly sensitive molecular tool for malaria parasite detection and species determination. PLoS One 10 (3): e0120210. DOI: 10.1371/journal.pone.0120210 